\title{
Uusioersily
}

\section{Digital Engagement: Strategies for Online Dramaturgy}

Dean, T. (2014). Digital Engagement: Strategies for Online Dramaturgy. In M. Romanska (Ed.), The Routledge Companion to Dramaturgy (pp. 500-504). Routledge.

Link to publication record in Ulster University Research Portal

\section{Published in:}

The Routledge Companion to Dramaturgy

Publication Status:

Published (in print/issue): 01/01/2014

\section{Document Version}

Publisher's PDF, also known as Version of record

\section{General rights}

Copyright for the publications made accessible via Ulster University's Research Portal is retained by the author(s) and / or other copyright owners and it is a condition of accessing these publications that users recognise and abide by the legal requirements associated with these rights.

\section{Take down policy}

The Research Portal is Ulster University's institutional repository that provides access to Ulster's research outputs. Every effort has been made to ensure that content in the Research Portal does not infringe any person's rights, or applicable UK laws. If you discover content in the Research Portal that you believe breaches copyright or violates any law, please contact pure-support@ulster.ac.uk. 


\section{3 \\ Digital engagement \\ Strategies for online dramaturgy}

Tanya Dean

The goal of this article is to offer resources to any dramaturg or literary manager seeking to take advantage of the internet as a medium to facilitate critical thinking and dialogue about theatre. For theatres that are committed to maintaining a dynamic online presence, successful digital dramaturgy is not necessarily reliant on cutting-edge technology. The three companies interviewed for this article - the Guthrie Theater in Minneapolis, Oregon Shakespeare Festival, and the National Theatre in London --.each have very different digital presences, but they share one common factor: a strategic focus on what their available digital resources could offer audiences, and how they might extend dramaturgical conversation beyond the theatre space.

\section{Guthrie Theater}

The Guthrie Theater enjoys a long-standing reputation for producing carefully curated and researched Play Guides to accompany their productions. The first Play Guide was produced in 1975, intended as a resource primarily for teachers to supplement their classroom work, and by the mid 1980s Play Guides were being created for most productions in the season. These guides are primarily the remit of the dramaturg for any given production; he/she is in charge of curating and producing the Play Guide, aided by a literary intern to assist in the research and writing. For the 2000 2001 season, the Guthrie decided to make the Play Guides available online. This meant that the format of the guide had to adjust to consider the legal repercussions of publishing on the internet. "Previously we'd used several longer pieces, sometimes of several pages. Because we were doing very limited print runs (300 perhaps), we could ask permission for those pieces and if a fee was required it was often minimal," explains Carla Steen, publications manager/dramaturg for the Guthrie. ${ }^{1}$ But since a digital publication has the potential to live in perpetuity online and be readily accessible to anyone, this changed the relationship with copyright holders. "So the content has taken the form of many smaller quotes that can be used within fair-use copyright guidelines."2 
In keeping with their origins as hard-copy study guides, the Play Guides available on the Guthrie website are primarily print-driven in terms of format and style, but designed to be appealing and navigable as an online resource as well. Steen explains that the PDFs of the Play Guides also "have links within the documents and are iPad compatible." The Play Guides are posted under the education section of the website and linked to the corresponding show page's resources. The Play Guides are also all archived online as PDFs, serving as both a digital memory of the Guthrie's production history and as a valuable resource for students and professionals alike who might be working on these plays in the future.

"Because each show will have different needs and information available, each guide will be different," explains Steen. "But we generally include information in these categories: the play, the playwright, cultural context and the Guthrie production." 4 A standard Guthrie Play Guide would generally include under the following headings:

- The Play: a synopsis, list of characters, literary analysis (quotes about the play from reviews, from academic journals, etc.), quotes by the playwright about the play.

- The Playwright: a biography, quotes by and about the playwright if available, perhaps a timeline of the author's life and major cultural events (usually just for classic plays but not always).

- Cultural Context: usually material that has been generated because of the needs of the production (glossary of terms from the script, culturally relevant information about the world of the play).

- The Guthrie Production: focuses on the specifics of the Guthrie production of the play (director's and designers' statements, perhaps something from the playwright if applicable).

- Then there are the potential extras that a Play Guide might offer: Building the Production might include production photos and backstage information about the set, costumes, props, sound, wigs, etc. This is usually added about two weeks later, as the information is gathered during tech week and can't be completed until production photos are taken, edited, and made available. Most guides will also include a For Further Reading section that will include books, articles, websites, films, and other additional resources that a reader or playgoer may find useful. Some guides may also include a Questions for Discussion page, usually for productions that would have a particular appeal to student groups.

While some dramaturgical materials are also made available in the program that is handed out when the audience physically arrives at the theatre, these can only "skim the surface," says Steen. "The play guide is intended to be a deeper dive into the material. We have an intelligent audience that enjoys knowing more about the work they see ... enriching the experience onstage is definitely embraced by our audience and, I think, Twin Cities audiences in general." 5

\section{Oregon Shakespeare Festival}

When Julie Felise Dubiner, an associate director at Oregon Shakespeare Festival (OSF), is working on online dramaturgical content for OSF, she enjoys knowing that 
this content is being created for a "rabidly loyal audience." "OSF is blessed with a core audience of theatrelovers who are more interested in the intellectual stuff. There are people who have been coming to OSF for generations, people who have seen the entire Shakespeare canon ... twice!" ${ }^{6}$ For OSF, online dramaturgy is part of an ongoing conversation that is passionate and enthusiastic on both sides. OSF has had a website since the mid 1990s, which underwent a major redesign in 2012, with the intent of making the format less formal and more accessible. Key to this is the "Connect with Us" blog section of the website, which offers dramaturgical supplements such as articles, interviews, audio, and video clips. As OSF has a company photographer, they also always have high-quality, beautiful photos to share online. The Marketing and Communications Department maintain the website, but the dramaturgs and associate directors have been given direct access, allowing them to upload dramaturgical materials as they become available. Dubiner admits that there have been adjustments to this instant online publication, but feels that overall they are positive: "There's probably less good writing coming out, but the immediacy of the conversation makes it more powerful than any beautiful sentence I could construct over the course of three months."7

OSF has an active Twitter (@OSFashland) and Facebook page, where the idea of interacting with the audience really comes into play. These are maintained by the Marketing and Communications Department, with a number of people who participate or who are linked in (such as dramaturgs or guests from the cast or creative team). Dubiner says that these not only keep the dialogue between OSF and its audience vivified, they also bring them into a larger discourse: "Being in nowheresville, Ashland, it's great letting people across the country know what the function of our festival is, and it helps keep a conversation going nationally." Dubiner's ambition is that this conversation will also help propel productions and playwrights towards life beyond OSF: "I get a lot of requests from people for scripts that I didn't hear from before I joined Twitter. We get a lot of interest from people who can't make it out here to see things, and want to learn more." 9

OSF strives for regular postings on Facebook and Twitter, explains Eddie Wallace, the membership and sales manager at OSF: "We plug upcoming events, highlight good reviews, share new photos from dress rehearsals, share interesting articles from out in the arts industry or about Shakespeare, have the occasional contest, show fun photos from our Archives." 10 And Facebook followers offer immediate engaged feedback, posting comments on OSF Facebook posts. "When someone is fabulously effusive about the work they've seen, we thank them and encourage them to come back soon," says Wallace. "We don't have a written policy about responding to digital comments, but our overall company policy is that every letter or question or deep comment should get a response." 11

As a "destination theatre," there is also a marked difference in how the website is valuable to both audience and festival. "People plan their trips to this festival differently from how they would plan trips to regional theatres. Our Marketing Department says that people tend to spend more time on our website than on the average 5-6 show season website," explains Dubiner. "If an audience member is coming for 5 days, and choosing from 11 shows, they will spend more time on website planning." 12 As such, digital content and dramaturgical resources become valuable tools to the 
theatrical pilgrims who journey to OSF every year. Dubiner says she feels that the website has replaced the idea of the old-school dramaturgy packet, meaning that the audience, cast, and creative team can now all become part of the dramaturgical conversation behind a particular production or a season theme. "The same pictures that I would previously have been photocopying 20 times for a rehearsal room dramaturgy packet, now I can post them online and suddenly the world can see what we're thinking about with this production. And we have a magnificently dedicated audience who will pay attention to these things."13

\section{National Theatre}

The average footfall through the National Theatre (NT) in London is approximately 600,000 people per year, according to Digital Content Producer Maya Gabrielle. ${ }^{1 / 4}$ Online, however, the NT reaches a vast international audience; on average, the NT's views/downloads/streams average 1.6 million hits annually. ${ }^{15}$ And that is going up exponentially each year, says Gabrielle, largely due to the extensive presence that the NT has worked to build on the web. The key, in Gabrielle's opinion, is to find the online hubs for audiences who are interested in and/or passionate about theatre (such as iTunes, iTunes U, YouTube, Sound Cloud) and make sure that the NT's dramaturgical materials are made available there as well as on the NT website. "This is one of the reasons why we are particularly good at developing digital content," she concludes. "We don't wait for people to come to us; we go to them."16

The NT employs a dedicated Digital Media Department; in addition to Gabrielle and David Sabel (head of Digital and executive producer of NT Live broadcasts), there is also an assistant producer, two in-house camera operators, film editors, and a pool of freelancers. The department produces dramaturgical materials on several different strands, including Digital Classroom, YouTube videos, podcasts (related to live events), and iTunes U. The Digital Media Department also invests considerable time in researching the impact and efficacy of their work and finding potential new avenues to explore. For example, the NT has a teacher focus group from a variety of schools and educational institutions from across the UK that meets quarterly and shares feedback on the NT's supplemental dramaturgical offerings. Gabrielle clarifies that the Digital Media Department is not a service department; rather, it is a creative department. "It's not about marketing, it's about sharing the excellence of the artists that we're lucky enough to have in this building." 17 This is in part related to the NT's status as a government-subsidized body, Gabrielle observes, "In response to the tax payer giving a little bit of money from their purse, we want to share as much as possible with them of what's happening." 18

As the NT produces between 23 and 26 performances per year, spread across 3 different auditoria within the South Bank complex, the Digital Media Department has to be selective about which productions they produce supplemental video materials for. ${ }^{19}$ As such, the focus is on productions that will reach the widest audience (such as the NT Live broadcasts, of which there are eight per year) and productions that are important educationally, particularly in the UK syllabus (with Shakespeare unsurprisingly a priority). ${ }^{20}$ Rather than focus on the specifics of the 
production itself, Gabrielle tries to find larger themes within the play that will resonate with audiences long past the final performance. "Digital content is not cheap to make and we don't charge people to view it. So if production is only up for three months, I try and produce films that will have a shelf-life of between five to ten years, so I can justify the expense of making it." 21

In a talk entitled "The Power of Online Video" (available on YouTube) she gave in 2011 for a digital seminar at Sadler's Wells, Gabrielle noted the serendipity of the popularity of the NT's videos beyond the obvious audience of passionate theategoers.

We were expecting Danny Boyle's Frankenstein and War Horse (seen by over a million people) to be the most popular. [But] the most popular collection of content that we put up on iTunes $U$ was a simple voice collection with some warm-up exercises and how to breathe and articulate, because people ... do want to learn, they want basic instructional stuff ... It hadn't even occurred to us that that was valuable until we put it into that forum. ${ }^{22}$

At the same talk, Gabrielle also discussed the potential for collaboration offered by online platforms, citing the example of a project that the NT initiated with the Royal College of Art in tandem with Frankenstein, where students created short videos based on their experience of the production. This, emphasized Gabrielle, was an example of digital dramaturgy that was a cost-effective way of both engaging the audience and broadening the experience of a production. "None of this content cost any money ... this is user-generated content. We provided a platform to put it up; it's very good quality, it's on brand, it's absolutely connected to one of our productions." 23

As an example of cost-effective online dramaturgy, Gabrielle showed a short video diary with rehearsal room footage from One Man, Two Guwnors, filmed by one of the actors with a Flip camera. Gabrielle explained that the Digital Media Department often give Flip cameras to members of the cast or staff directors or dancers (such as Fela) who are happy to film their experiences. She explained that the poor quality of the video becomes secondary to the insight into the rehearsal room that is being offered, because the people making the footage are a part of the creative experience. "[These videos] all cost nothing to shoot ... and what you sacrifice in quality video product, you can regain in the interest of the subject and the kind of access that you're giving the video viewer." 24 Gabrielle also offered key advice for smaller arts organizations that do not have the personnel or the resources to produce high-level digital content.

You need to think, who are your audiences? What is the asset you are offering? If you can't spend a lot of money on having a great crew with great sound and making it look slick, what can you offer that somebody else can't? You can offer something; all of you who've got different creative processes that you're exploring, or different artists that you're working with, all of you have something unique and it doesn't necessarily need to be expensive to expose it. ${ }^{25}$ 


\section{Notes}

1 Carla Steen, publications manager/dramaturg, Guthrie Theater, interview by Tanya Dean, March 27, 2013.

2 Steen, interview.

3 Steen, interview.

4 Steen, interview.

5 Steen, interview.

6 Julie Felise Dubiner, associate director, Oregon Shakespeare Festival, interview by Tanya Dean, April 1, 2013.

7 Dubiner, interview.

8 Dubiner, interview.

9 Dubiner, interview.

10 Eddie Wallace, membership and sales manager, Oregon Shakespeare Festival, interview by Tanya Dean, April 1, 2013.

11 Wallace, interview.

12 Wallace, interview.

13 Wallace, interview.

14 Maya Gabrielle, digital content producer, National Theatre, interview by Tanya Dean, May 2, 2013.

15 Gabrielle, interview.

16 Gabrielle, interview.

17 Gabrielle, interview.

18 Gabrielle, interview.

19 Gabrielle, interview.

20 Gabrielle, interview.

21 Gabrielle, interview.

22 Maya Gabrielle, "The Power of Online Video" (2011), available online at https:/www. youtube.com/watch?v=TvQ33v4GA_U, accessed May 10, 2013.

23 Gabrielle, video.

24 Gabrielle, video.

25 Gabrielle, video. 


\title{
THE ROUTLEDGE COMPANION TO DRAMATURGY
}

\author{
Edited by \\ Magda Romanska
}


First published in paperback 2016

First published 2015

by Routledge

2 Park Square, Milton Park, Abingdon, Oxon OX144RN

and by Routledge

711 Third Avenue, New York, NY 10017

Routledge is an imprint of the Taylor of Francis Group, an informa business

(c) 2015,2016 Magda Romanska for selection and editorial matter; individual contributions, the contributors

The right of Magda Romanska to be identifed as author of the editorial material and of the authors for their individual chapters has been asserted in accordance with sections 77 and 78 of the Copyright, Designs and Patents Act 1988.

All rights reserved. No part of this book may be reprinted or reptoduced or utilised in any form or by any electronic, mechanical, or other means, now known or hereafter invented, including photocopying and recording, or in any information storage or retrieval system, without permission in writing from the publishers.

Trademark notice: Product or corporate names may be trademarks or registered trademarks, and are used only for identification and explanation without intent to infringe.

British Library Cataloguing in Publication Data

A catalogue tecord for this book is avalable from the British Library

Library of Congress Cataloguing in Publication Data

The Routledge companion to dramaturgy / ledited] by Magda Romanska. pages $\mathrm{cm}$

Includes bibliographical references and index.

1. Theater-Ptoduction and direction. 2. Dramaturges. I. Romanska, Magda, editor of compilation. II. Title.

PN2053.R78 2014

$792.02 \div 3-\mathrm{dc} 23$

2014002637

ISBN: 978-0-415-65849-2 (hbk)

ISBN: 978-1-138-94633-0 (pok)

ISBN: 978-0-203-07594-4 (ebk)

Typeset in Goudy

by Taylor \& Francis Books 